\title{
Türk Mutfağında Yeni Bir Fonksiyonel Gıda Olarak Siyah Sarımsak (Allium sativum L.): Fenolik Madde İçeriği ve Bakteriyel İletişim (Quorum Sensing) Üzerine Etkisi
}

\author{
Ayşe Gül Özaydın ${ }^{(\text {(i) }} \square$, Evren Arın² ${ }^{(i D)}$, Ebru Önem³ \\ ${ }^{1}$ Süleyman Demirel Üniversitesi, Yenilikçi Teknolojiler Uygulama ve Araştırma Merkezi, Isparta \\ ${ }^{2}$ Süleyman Demirel Üniversitesi, Sağlık Hizmetleri Meslek Yüksekokulu, Isparta \\ ${ }^{3}$ Süleyman Demirel Üniversitesi, Eczacılık Fakültesi, Isparta \\ Geliş Tarihi (Received): 03.02.2020, Kabul Tarihi (Accepted): 28.03.2020 \\ Yazışmalardan Sorumlu Yazar (Corresponding author): ayseozaydin@sdu.edu.tr (A.G. Özaydın) \\ (C) 02462118072 边 02462111963
}

öz

Sarımsak (Allium sativum L.) insan sağlığına yararlı olduğu bilinen ve dünya mutfağında çok eski zamanlardan bu yana yer alan bir sebzedir. Sarımsağın karakteristik kokusu ve tadı nedeniyle çiğ olarak tüketimi sınırıdır. Bu nedenle son yıllarda sağlığa yararlı etkileri korunarak, istenmeyen kokularından izole edilmiş yeni sarımsak ürünlerinin eldesi için birçok metot denenmektedir. Bu amaçla üretilmiş olan siyah sarımsak birçok ülke ve hatta ülkemizde çok fazla bilinmemekte ve tüketilmemektedir. Yapılan bu çalışma ile siyah sarımsağın yapısında bulunan bazı fenolik bileşikler Yüksek Performanslı Sıvı Kromatografisi (HPLC) ile araştııımıştır. Ayrıca metanol ile hazırlanan ekstraktının Pseudomonas aeruginosa PA01'in sentezlediği ve patogenezinde önemli rolü olan piyosiyanin ve elastaz üretimi ile biyofilm oluşumu üzerine inhibisyon etkisine bakılmıştır. HPLC analiz sonuçlarına göre fenolik bileşiklerden kuersetin, klorojenik asit, vanillin, $p$-kumarik asit, $p$-hidroksi benzoik asit farklı oranlarda tespit edilmiştir. Mikrobiyal aktivite sonuçlarına göre ise siyah sarımsak metanol ekstraktının piyosiyanin ve elastaz üretimi ile biyofilm oluşumu üzerine (sırasıyla \%38, \%28 ve \%84 inhibisyon oranlarıyla) inhibisyon etkisinin anlamlı olduğu görülmüştür.

Anahtar Kelimeler: Siyah sarımsak, Fenolik bileşikler, Biyofilm, Pseudomonas aeruginosa PA01

\section{Black Garlic (Allium sativum L.) as a New Functional Food in Turkish Cuisine: Phenolic Content and Effect on Bacterial Communication (Quorum Sensing)}

\begin{abstract}
Garlic (Allium sativum L.) is a vegetable known to be beneficial to human health and has been in the world cuisine since ancient times. The consumption of garlic is limited due to its characteristic odor and taste. For this reason, in recent years many methods have been tried to obtain new garlic products isolated from their undesired odors while preserving their beneficial health effects. Black garlic produced for this purpose is not known and consumed in many countries including Turkey. In the present study, the phenolic content of black garlic was determined by High Performance Liquid Chromatography (HPLC). In addition, the inhibition effect of methanol extract on some virulence factors such as pyocyanin, elastase and biofilm formation, which has an important role in the pathogenesis of Pseudomonas aeruginosa PA01, was investigated. As a result, quercetin, chlorogenic acid, vanillin, $p$-coumaric acid,
\end{abstract}


p-hydroxy benzoic acid were detected in different concentrations. According to the results of microbial activity tests, the inhibition effect of black garlic methanolic extract on the production of pyocyanin, elastase and biofilm formation (38, 28 and $84 \%$ inhibition ratios, respectively) was found significant.

Keywords: Black garlic, Phenolic compounds, Biofilm, Pseudomonas aeruginosa PA01

\section{GíRiş}

Sarımsak (Allium sativum L.), Alliaceae familyasına ait Allium cinsinden soğanlı bir bitki türüdür. Sarımsak tarih boyunca bütün dünyada farklı kültürlerin mutfaklarında hem baharat ve yiyecek olarak hem de tedavi amaçlı kullanılmıştır. Sarımsak ilk defa bilim dünyasına 1753 yılında İsviçreli botanikçi Linne tarafından tanıtılmıştır. Anavatanı Orta ve Batı Asya olarak kabul edilen sarımsağın dünyada 700 çeşidi vardır. Sarımsağın sağlık üzerine olan olumlu etkisinin 5000 yıldan beri bilindiği Babilliler, Mısırlılar, Romalılar, Çinliler, Yunanlılar ve Hindular tarafından çok yaygın bir şekilde kullanıldığı belirtilmektedir. Doğal antibiyotik olarak bilinen sarımsağın hipoglisemi, diyabet ve hipertansiyon üzerinde tedavi edici özelliğe sahip olduğu; antibakteriyel, antifungal ve antikanserojen etkiler gösterdiği yapılan birçok çalışma ile rapor edilmiştir [15].

TÜIK verilerine göre, Türkiye'de toplam sarımsak üretim miktarı 2018 yılında 143207 ton (117 688 ton kuru, 25519 ton taze) ve 2019 yılında ise 126447 tondur (103 096 ton kuru, 23351 ton taze). Sarımsak dendiğinde akla ilk gelen il Kastamonu olmasına karşın, son yıllarda artan sarımsak üretimi ile Gaziantep ilimiz dikkat çekmektedir. Sarımsak üretiminin en yüksek olduğu iller 2018 ve 2019 yılları için sırasıyla Gaziantep, Kastamonu ve Kahramanmaraş olmuştur [6].

Sarımsağın karakteristik kokusu ve tadı nedeniyle gıda ve ilaç olarak kullanımı ve tüketimi sınırlıdır. Bu nedenle sarımsak tüketimi ve kullanımının yaygınlaşmasında etkili olabilecek birçok alternatif sarımsak ürünü piyasada yerini almıştır. Kurutulmuş sarımsak, sarımsak tozu, sarımsak yağı, sarımsak tozu tabletleri, kapsülleri bunlardan bazılarıdır. Son yıllarda sarımsağın rahatsız edici kokusunu gidermek ve lezzetini artırmak için ısıl işlem ve fermantasyon gibi çeşitli işleme yöntemleri kullanılmaya başlanmıştır $[7,8]$.

Taze sarımsağın yüksek sıcaklık ve kontrollü nem altında 1 aydan uzun süre (30-40 gün) Isıl işlem uygulaması sonucu elde edilen siyah sarımsak taze sarımsağa alternatif olarak görülen en dikkat çekici üründür. Fermantasyon sıcaklığı siyah sarımsak üretiminde önemli bir parametre olup, fermentasyon sıcaklığının $70^{\circ} \mathrm{C}$ olduğu üretimlerde siyah sarımsağın; renk, tekstür ve tat yönünden uygun yapı kazandığı yapılan çalışmalarla ortaya konmuştur. Düşük sıcaklıklarda istenilen siyah rengin tam olarak oluşmadığı; yüksek sıcaklıklarda ise acımsı ve ekşi bir tat ortaya çıktığı belirtilmiştir. Yapılan son çalışmalarda siyah sarımsak üretimi için optimum koşulların $70^{\circ} \mathrm{C}$ ve $\% 80-90$ bağıl nemde, $30-40$ gün süreyle gerçekleştirildiği görülmektedir. Üretim prosesi sonunda oluşan ürün tamamen siyah renkli, kokusuz ve elastik yapıdadır $[8,9,10]$.

Siyah sarımsak ve siyah sarımsaktan elde edilen ürünler, sarımsağın sağlık yararlarının artan farkındalığı ile birlikte Kore pazarında çok uzun yıllar önce en hızlı büyüyen sağlık odaklı gıdalardan biri olmuştur. Bunun yanında siyah sarımsak uzun yıllardır Güney Kore, Japonya ve Tayland'da da tüketilmektedir. Son yıllarda ise popülaritesi dünya geneline yayılmış ve mutfaklarda sıkça kullanılan bir ürün haline gelmiştir. Özellikle gastronomi uzmanlarının birçok yemeği tatlandırmak için siyah sarımsak kullanmaları dikkat çekici olmuş ve siyah sarımsak kullanımının yaygınlaşmasını sağlamıştır [9, 11-15].

Sarımsak ısıl işleme tabi tutulduğu zaman lezzet, renk ve besin içeriğinde önemli fizikokimyasal değişiklikler meydana gelir. Asitlik değeri artar, karakteristik kokusunu kaybeder ve yoğun tatı bir tat oluşur. Biyokimyasal içeriğinde ise toplam polifenol içeriği ve antioksidan kapasitesinin arttığı görülür. Siyah sarımsağın eldesinde kullanılan ısıl işlem özellikle, Maillard reaksiyonu ve fenollerin kimyasal oksidasyonu gibi enzimatik olmayan esmerleşme reaksiyonlarına neden olur. Enzimatik olmayan esmerleşme reaksiyonları güçlü antioksidan özelliklere sahip bileşiklerin oluşumu ile ilişkili olduğu bilinmektedir $[7,8$, $14,16]$.

Taze sarımsağın yapısında alliin, allisin ve S-alililsistein (SAC) gibi kükürtlü bileşikler bulunmakta olup, allisin taze sarımsaktaki tat ve kokudan sorumludur. Sarımsağın fermantasyonu sırasında allinaz enziminin parçalanması sonucu, alliinin allisine dönüşümü engellenmektedir. Böylece sarımsaktaki karakteristik koku azalmaktadır. Alliin S-allilsisteine (SAC) dönüşmekte, kokusuz bileşenler oluşmaya başlamaktadır. SAC miktarı siyah sarımsak oluşumunda artarken; alliin, allisin ve polisakkarit oranı azalmaktadır. Bae ve ark. [13], S-allilsistein miktarı $19.61 \mu \mathrm{g} / \mathrm{g}$ olan taze sarımsağın $40^{\circ} \mathrm{C}$ 'de 45 gün fermente edilmesi sonucu oluşan siyah sarımsakta $124.67 \mu \mathrm{g} / \mathrm{g}$ 'a çıktığını bildirmişlerdir [8, 10, 12, 13, 17-19].

Birçok araştırmacı yaptıkları çalışmalarla siyah sarımsağın taze sarımsağa göre daha güçlü antioksidan aktiviteye sahip olduğunu ve metabolik hastalıkları 
önleyici etkileriyle insan sağlığında koruyucu rol oynadığını belirtmişlerdir. Choi ve ark. [20] yaptıkları çalışmada toplam polifenol ve toplam flavonoid içeriği dahil olmak üzere antioksidan bileşenlerin fermantasyonun 21. gününe kadar önemli ölçüde arttığını $(p<0.05)$ belirtmişlerdir. Antioksidan içeriğini en üst düzeye çıkarmak için siyah sarımsağın optimum fermantasyon süresinin 21. gün olabileceği sonucuna varmışlardır $[8,13,15,16,20,21]$.

Literatürde yer alan son çalışmalar siyah sarımsağın; diyabet ve obeziteye karşı korunmada etkili olduğunu, kanser önleyici etkisinin taze sarımsaktan daha fazla olduğunu, kalp-damar hastalıklarının oluşma riskini azalttığını göstermiştir. Ayrıca siyah sarımsağın lipid peroksidasyonunu azalttığı, obeziteyi baskıladığı ve kandaki yağ oranını düşürdüğü yapılan çalışmalarda tespit edilmiştir. Purev ve ark. [22] yılında Kore'de 21 gönüllü üzerinde bağışıklık sistemi hücrelerini izole ederek yaptıkları çalışmada, siyah sarımsak ile taze sarımsağın bağışıklık sisteminin anti-kanserojen ve antioksidan aktivite ile doğrudan ilişkili olduğunu ve siyah sarımsakta bağışıklık sistemi hücrelerinin çok daha baskın olduğunu belirtmişlerdir. Yine yapılan çalışmalarda taze sarımsağın olduğu gibi siyah sarımsağın da antibakteriyel etkiye sahip olduğu bilinmektedir (4, 22-24). Fakat son yıllarda bakterilerle olan mücadelede doğala yönelim etkili ve başarılı bir tercih gibi görülmekle beraber enfeksiyonlardan sorumlu olan bakterilerde patojeniteden sorumlu olan çevreyi algılama sisteminin (Quorum Sensing, QS) inhibisyonu, bakterilerle mücadelede üzerinde çok fazla durulan seçeneklerden biri olmuştur. Bakteriler arasındaki iletişimi ifade eden bu sistemin temeli, bakterilerin bulundukları ortama sinyal molekülü olarak adlandırılan bir takım maddeleri sentezlemeleri ve sentezlenen bu maddelerin yoğunluğu ile ortamdaki popülasyon yoğunluklarını algılayarak bazı özel genlerin ekspresyonun gerçekleştirilmesidir [25]. Bakterilerde bu şekliyle yüzlerce kollektif davranış mevcuttur, fakat bunlar içerisinde en önemli olanı virülens faktörlerinin sentezidir [26].

Pseudomonas aeruginosa özellikle ağır seyirli hastane enfeksiyonlarında, bağışıklık sistemi baskılanmış hastalarda, kistik fibroz hastalarında kronik enfeksiyonlar oluşturan fırsatçı bir patojen olup patogenezinde önemli rolü olan elastaz, piyosiyanin, biyofilm oluşumu gibi virülans faktörlerinin salınımını çevreyi algılama sistemi kontrolünde gerçekleştirmektedir.

$\mathrm{Bu}$ çalışma ile son yıllarda popülaritesi artan siyah sarımsağın içerdiği fenolik bileşikler HPLC kullanılarak araştırılmış, bakteriler arası iletişimden sorumlu olan QS temelli bazı virülans faktörlerinin (piyosiyanin, elastaz ve biyofilm oluşumu) üretimi üzerine inhibisyon özelliğinin belirlenmesi amaçlanmıştır.

\section{MATERYAL VE METOT}

\section{Bitki Ekstraksiyonu}

Çalışmada kullanılan siyah sarımsak ticari (EdovitalKastamonu) olarak temin edilmiş olup, firmanın üretim koşullarının, hasat edilen mevsim şartları dikkate alınarak, \%80-90 nem aralığında, $60-80^{\circ} \mathrm{C}$ sıcaklıkta, 46 hafta süreyle olduğu bildirilmiştir. Çelik blender (Waring $8011 \mathrm{~EB}$ ) yardımı ile parçalanan örnekten $20 \mathrm{gr}$ tartılarak 100 mL çözücü metanol eklenmiştir. Çözücüörnek karışımı 15 dakika ultrasonik banyoda bekletildikten sonra kaba filtre kâğıdı ile süzülmüş ve vakum altında $40-45^{\circ} \mathrm{C}$ sıcaklıkta rotary evaporatörde (Heidolph Hei-Vap Rotary Evaporator) çözücü uzaklaştırılmıştır. Balon içerisinde kalan sarımsak özütü tartılarak kaydedilmiş ve metanol ile alınmıştır.

\section{Fenolik Bileşiklerin HPLC ile Tayini}

Fenolik bileşiklerin belirlenmesinde HPLC yöntemi kullanılmıştır. Analizler Süleyman Demirel Üniversitesi, YETEM, Uygulamalı Temel Bilimler ve Teknolojileri Araştırma Birimi'nde gerçekleştirilmiştir. HPLC analizinde Gomes ve ark. [27] metodu kullanılmıştır, gradient program ayırımın daha iyi olması için modifiye edilmiştir [27]. Fenolik bileşiklerin tespiti Photo Diode Array dedektörde $278 \mathrm{~nm}$ dalga boyunda gerçekleştirilmiştir. Agilent Eclipse XDB C-18 (250x4.6 $\mathrm{mm}) 5 \mu \mathrm{m}$ kolon kullanılmış olup, ayırım gradient program uygulanarak yapılmıştır. Fenolik bileşik analizi üç tekerrürlü olarak gerçekleştirilmiştir. Analizde kullanılan HPLC cihazı (Shimadzu, Kyoto, Japonya), çalışma koşulları ve gradient program Tablo 1 ve 2'de verilmiştir.

Çalışmada tayini yapılan fenolik bileşikler, gallik asit, protokateşik asit, kateşin, p- hidroksi asit, klorojenik asit, kafeik asit, epikateşin, şiringic asit, vanillin, p-kumarik asit, ferulik asit, sinapinik asit, benzoik asit, rutin, hesperidin, rosmarinik asit, eriodiktiol, sinnnamik asit, kuersetin, luteolin, kamferol ve apigenindir. 14 adet fenolik asit ve 9 adet flavonol standardı kullanılmıştır. Bu 23 adet fenolik bileşiğin kolonda ayrımını gösteren kromatogram Şekil 1'de gösterilmiştir.

\section{Piyosiyanin Testi}

Siyah sarımsak metanol ekstraktının piyosiyanin pigment üretimi üzerine inhibisyon etkisini araştırmak için $37^{\circ} \mathrm{C}$ sıcaklıkta bir gece üretilmiş PA01 bakteri kültüründen 600 nm'de OD 0.05 olacak şekilde, içerisinde $10 \mathrm{~mL}$ LB besiyeri olan şişelere $100 \mu \mathrm{L}$ (son derişim 6,1 m) bitki ekstraktı ile birlikte eklenmiş ve $37^{\circ} \mathrm{C}$ 'de $16-18$ saat çalkalanarak inkübasyona bırakılmıştır. İnkübasyon süresinin ardından besiyerine 5 $\mathrm{mL}$ kloroform eklenmiş ve 30 saniye vortekslenmiştir. Şişelerin alt kısmında kloroformdan ayrı olan faz $2 \mathrm{~mL}$ olacak şekilde alınarak cam tüplere konulmuştur. 
A.G. Özaydın, E. Arın, E. Önem Akademik Gıda 18(1) (2020) 27-35

Üzerine $1 \mathrm{~mL}$ HCL-su karışımı ilave edilerek tekrar 30 saniye vortekslenmiş, tüplerin üst kısmında oluşan

pembe faz OD 520 nm'de okunarak kaydedilmiştir [28].

Tablo 1. HPLC çalışma koşulları

\begin{tabular}{ll}
\hline Parametre & Değer \\
\hline Dedektör & Photo Diode Array dedektör ( $\lambda$ max=278nm ) \\
Otomatik örnekleyici & SIL-10AD vp \\
Sistem kontrol & SCL-10Avp \\
Pompa & LC-10ADvp \\
Gaz giderici sistem & DGU-14A \\
Kolon fırını & CTO-10Avp \\
Kolon & Agilent Eclipse XDB C-18 (250x4,6 mm) $5 \mu \mathrm{m}$ \\
Kolon sıcaklığı & $30^{\circ} \mathrm{C}$ \\
Mobil faz & $\mathrm{A}=\mathrm{Su} /$ asetik asit $(97 / 3: \mathrm{v} / \mathrm{v}) \mathrm{pH}: 2.2$ \\
& $\mathrm{~B}=\mathrm{Metanol}$ \\
Akış hızı & $0.8 \mathrm{~mL} /$ dakika \\
Enjeksiyon hacmi & $20 \mu \mathrm{L}$ \\
\hline
\end{tabular}

Tablo 2. HPLC analizinde kullanılan gradient program*

\begin{tabular}{ccc}
\hline Süre (dakika) & $\mathrm{A}(\%)$ & $\mathrm{B}(\%)$ \\
\hline 0 & 93 & 7 \\
20 & 72 & 28 \\
28 & 75 & 25 \\
35 & 70 & 30 \\
50 & 70 & 30 \\
60 & 67 & 33 \\
62 & 58 & 42 \\
70 & 50 & 50 \\
73 & 30 & 70 \\
75 & 20 & 80 \\
80 & 0 & 100 \\
81 & 93 & 7 \\
\hline *: A=Su/asetik asit (97/3: $\mathrm{v} / \mathrm{v}), \mathrm{pH}: 2.2, \mathrm{~B}=$ Metanol
\end{tabular}

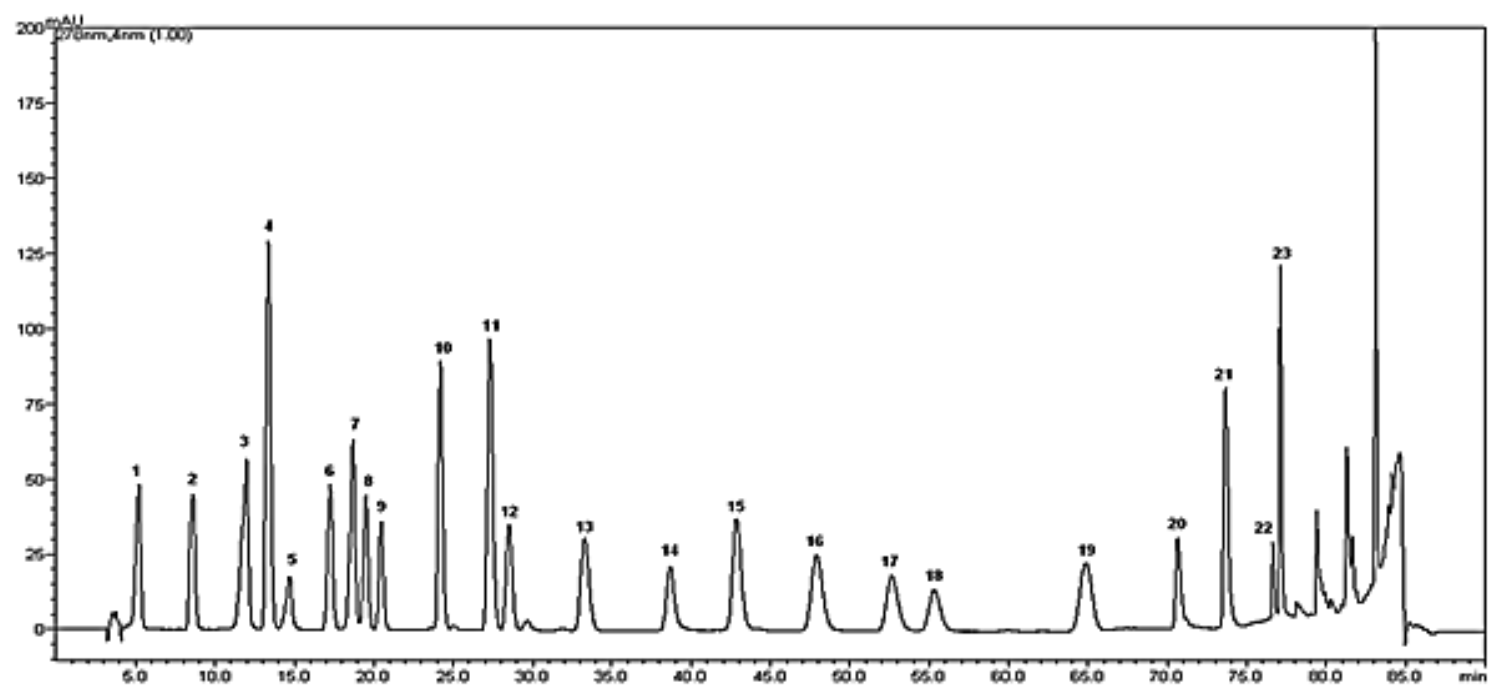

Şekil 1. Siyah sarımsakta bulunan fenolik bileşiklerin belirlenmesinde kullanılan standartlara ait kromatogram. 1. gallik asit 2. protokateşik asit 3. kateşin 4. p-hidroksi benzoik asit 5. klorojenik asit 6. kafeik asit 7. epikateşin 8. şiringic asit 9. vanillin 10. p-kumarik asit 11. ferulik asit 12. sinapinik asit 13. benzoik asit 14. o-kumarik asit 15 . rutin 16 . hesperidin 17. rosmarinik asit 18. eriodiktiol 19. sinnnamik asit 20. kuersetin 21. luteolin 22. kamferol ve 23. apigenindir. 


\section{Biyofilm Oluşum Testi}

Biyofilm oluşumu Kristal Viyole (CV) testi ile gerçekleştirilmiş bu amaçla 96 kuyucuklu mikro-plate kullanılmış ve kuyucuklara LB besiyeri, bakteri kültürü ve $10 \mu \mathrm{L}$ (son derişim 6,1 mg) siyah sarımsak ekstraktı eklenerek 48 saatlik inkübasyona bırakılmıştır. İnkübasyon sonunda plate içerisindeki kültürler dökülerek 3-5 kez saf su ile yıkanmıştır. Plate kuruduktan sonra kuyucuklara \%0,1 derişimdeki kristal viyole eklenmiş ve yarım saat bekletilmiştir. Süre sonunda plate yine saf su ile 3-5 kez yıkanmıştır. Yıkama işlemi tamamlandıktan sonra \%95'lik etanol ilavesiyle 15 dakika beklenmiş ve CV'nin çözdürülmesi sağlanmıştır. Sonuçlar 570 nm'de (Biotek -Epoch 2 Miproplate Spektrofotometre) kullanılarak okunmuştur [29].

\section{Elastaz Testi}

Elastin Kongo Red (ECR) testi ile yapılan çalışmada, PA01 sıvı kültüründen $600 \mathrm{~nm}$ de OD değeri belirlenip, 0.05 yoğunlukta $10 \mathrm{~mL}$ LB sıvı besiyerine $100 \mu \mathrm{L}$ (son derişim 6,1 mg) siyah sarımsak ekstraktı ile birlikte eklenmiş ve $37^{\circ} \mathrm{C}$ 'de, $14-16$ saat sure ile çalkalanarak inkübasyona bırakılmıştır. Bu kültürlerin supernatant kısmından $100 \mu \mathrm{L}, 900 \mu \mathrm{L}$ ECR tamponu (100 mM Tris, $1 \mathrm{mM} \mathrm{CaCl}, \mathrm{pH} 7.5,20 \mathrm{mg} E C R$ ) üzerine ilave edilmiş ve $37^{\circ} \mathrm{C}$ 'de 3 saat $200 \mathrm{rpm}$ de inkübasyona bırakılmıştır. İnkübasyon sonucunda çözülmemiş olan ECR santrifüj (DLAB-D2012plus) edilerek uzaklaştırılmış ve supernatant kısım OD 495 nm'de (Biotek-Epoch 2 Miproplate Spektrofotometre) okunmuştur [30].

\section{İstatistiksel Analiz}

Bu çalışma "tesadüf parselleri deneme desenine" göre dizayn edilmiş ve her uygulamada üç tekerrür kullanılmıştır. Veriler, JUMP istatistik paket programı ile varyans analizine (ANOVA) tabi tutulmuş ve uygulamalar arasındaki farklar LSD çoklu karşılaştırma testi ile değerlendirilmiştir.

\section{BULGULAR VE TARTIŞMA}

\section{Fenolik Bileşik Analiz Sonuçları}

Siyah sarımsak metanol ekstraktında tespit edilen fenolik bileşikler ve miktarları Tablo 3'de, fenolik bileşiklerin kromatogramı ise Şekil 2'de verilmiştir. Fenolik asitlerden; gallik asit, protokateşik asit, kafeik asit, şiringic asit, ferulik asit, sinapinik asit, benzoik asit, o-kumarik asit, rosmarinik asit, sinnamik asit ile flavonol grubundan kateşin, epikateşin, rutin, hesperidin, eriodiktiol, luteolin, kamferol ve apigenin ise tespit edilmemiştir. Tayin edilen fenolik asitler; $p$-hidroksi benzoik asit, klorojenik asit, vanillin ve $p$-kumarik asit olup, flavonol grubundan ise sadece kuersetin saptanmıştır. Major fenolik bileşik kuersetini $(7.7 \mu \mathrm{g} / \mathrm{g})$ sırasıyla $p$-hidroksi benzoik asit $(3.5 \mu \mathrm{g} / \mathrm{g})$ ve klorojenik asit $(2.8 \mu \mathrm{g} / \mathrm{g})$ takip etmektedir.

Tablo 3. Siyah sarımsakta bulunan fenolik bileşik miktarları

\begin{tabular}{lc}
\hline Fenolik asitler & $(\mu \mathrm{g} / \mathrm{g})$ \\
\hline$p$-Hidroksi benzoik asit & $3.5 \pm 0.3$ \\
Klorojenik asit & $2.8 \pm 0.1$ \\
Vanillin & $0.3 \pm 0.03$ \\
$\quad p$-Kumarik asit & $0.3 \pm 0.01$ \\
\hline Flavonoller & \\
$\quad$ Kuersetin & $7.7 \pm 1.0$ \\
\hline
\end{tabular}

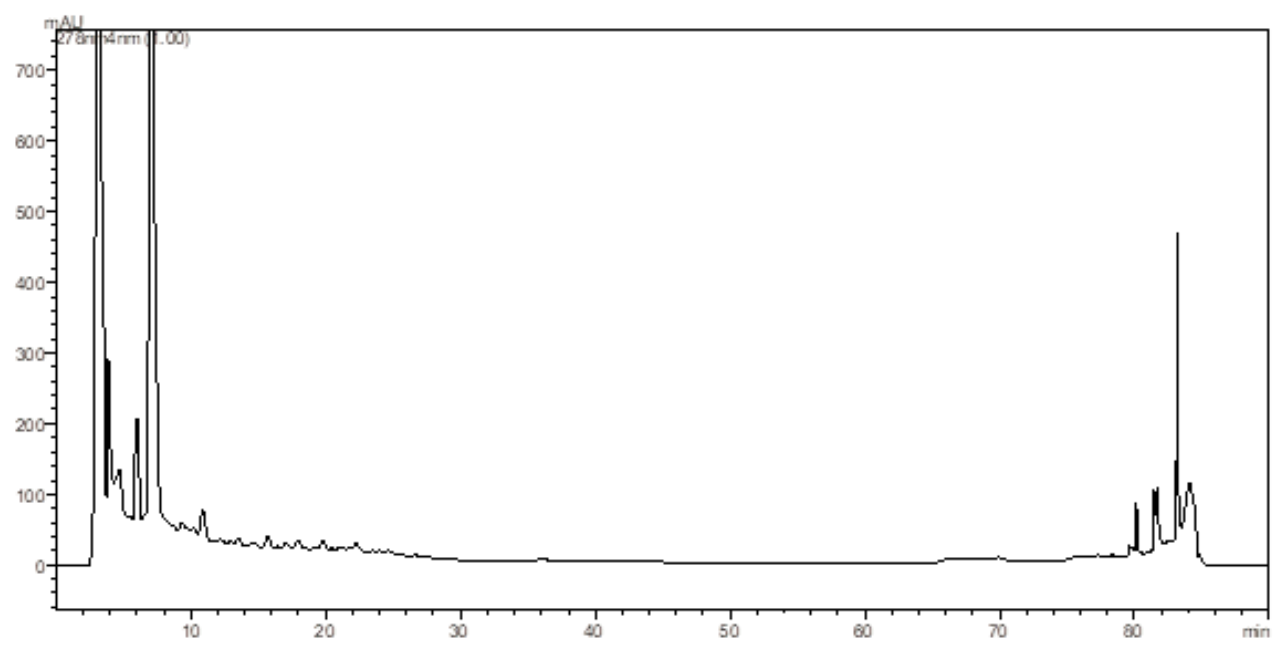

Şekil 2. Siyah sarımsak ekstraktında tespit edilen fenolik bileşiklere ait kromatogram 
Casas ve ark. [31] yaptıkları bir çalışmada; taze sarımsağın siyah sarımsağa dönüştürüldüğünde aroma profili, şekerler ve biyoaktif bileşiklerdeki değişiklikleri araştırmışlardır. Taze sarımsağın siyah sarımsak haline dönüşümünde fenolik asit ve flavonoid seviyelerinde önemli değişiklikler olduğunu belirtmişlerdir. Fenolik asitlerden, kafeik, klorojenik, kumarik ve ferulik asit ile flavonoidlerden, epikateşin ve apigenini tespit etmişlerdir. Siyah sarımsak örneklerini taze sarımsak ile karşılaştırdıklarında; fenolik asitlerden sırasıyla klorojenik asit ile kafeik asitin taze sarımsakta $11.71 \pm 9.31 \mathrm{mg} / 100 \mathrm{~g}$ ve $3.45 \pm 1.76 \mathrm{mg} / 100 \mathrm{~g}$ iken siyah sarımsakta tespit edilmediğini belirtmişlerdir. Bununla birlikte, kumarik asit ve epikateşin seviyelerinde önemli ölçüde artış olduğu bulmuşlardır. Fenolik asitlerin ve flavonoidlerin bileşiminin yaşlanma sürecinde önemli ölçüde değiştiğinin, bazılarının arttıkça, diğerlerinin tamamen veya büyük ölçüde kaybolduğunun sonucuna varmışlardır [31].

Bizim yaptığımız fenolik bileşik analizinde de kafeik asit tespit edilmemiştir. Bu durumun siyah sarımsak üretilirken maruz bırakılan ısıl işlemden kaynaklandığı düşünülmektedir.

Bir grup araştırmacı siyah sarımsağın baş ve soyulmuş halinin üç farklı ısıl işlem sıcaklığında $\left(72,75\right.$ ve $\left.78^{\circ} \mathrm{C}\right)$ fizikokimyasal ve antioksidan özelliklerini incelemişlerdir. Sarımsaktaki toplam polifenol içeriğinin tüm ısıtma işlemlerinde artı̆ğını belirtmişlerdir. Ayrıca polifenollerin miktarının soyulmamiş halinde 3 kat, soyulmuş siyah sarımsakta yaklaşık 6 kat artış gösterdiğini tespit etmişlerdir [14].

Kore'de yapılan bir çalışmada, taze sarımsaklar farklı sıcaklık, nisbi nem ve sürelerde tutularak oluşan siyah sarımsaktaki toplam fenol ve flavanoid içerikleri araştırımıştır. Yapılan sıcaklık uygulamalarının siyah sarımsakta fenolik asit ve flavanoid içeriğini arttığını, bununla birlikte toplam fenolik bileşik miktarının, toplam flavonoid miktarından fazla olduğunu tespit etmişlerdir. Bununla birlikte $70^{\circ} \mathrm{C}$ 'de $\% 60$ nispi nemde 60 saat tutulan sarımsaklarda toplam flavanoid madde miktarının toplam fenolik bileşik miktarından daha fazla olduğunu belirtmişlerdir. Ayrıca hidrosinnamik asit türevlerinin tüm farklı sıcaklık koşullarında tutulan sarımsaklarda en önemli fenolik asit olduğunu bulmuşlardır. Araştırmacılar inceledikleri siyah sarımsaklarda flavonol grubundan kamferol ve apigenin tespit edilmediğini, kuersetin miktarının $1.70 \pm 0.09$ ile $7.31 \pm 0.18 \mathrm{mg} / \mathrm{kg}$ arasında olduğunu belirtmişlerdir. Yaptığımız çalışmada kamferol ve apigenin tespit edilmemiş olup, kuercetin miktarı da benzerlik göstermektedir [32].

Eyüpoğlu [33] yaptığı çalşmada siyah sarımsağın antioksidan aktivite ve fenolik içeriğini araştırmıştır. Tespit ettiği 13 fenolik bileşik içerisinden; klorojenik asit, vanilik asit, benzoik asit ve gallik asit içeriğinin oldukça yüksek olduğunu ve vanilik asitin $(750.95 \pm 0.01 \mathrm{mg} / \mathrm{L})$ en yüksek oranda olduğunu belirtmiştir. Araştırma sonuçlarına benzer olarak bizim yaptığımız çalışmada da klorojenik asit, p-hidroksi benzoik asit ve vanillin tespit edilmiştir [33].

Koca ve ark. [34] Çin ve Taşköprü siyah sarımsaklarının fiziksel ve kimyasal özelliklerini araştırdıkları çalışmalarında; Çin siyah sarımsağının antioksidan gücü ve toplam fenolik içeriğinin Taşköprü siyah sarımsak değerlerinden daha yüksek olduğunu fakat istatistiksel olarak anlamlı olmadığını $(P>0.05)$ belirtmişlerdir [34].

Yaptığımız çalışmada fenolik bileşiklerin analiz sonuçları diğer araştırmacıların çalışmalarıyla benzerlikler göstermektedir. Tespit edilen fenolik bileşikler; pkumarik asit [28, 29], klorojenik asit [28-30], kuersetin [29] ve vanillin [30] diğer araştırmalarda da tespit edilmiştir. Araştırma sonuçlarına bakıldığında 23 adet fenolik bileşiklerden tespit edemediğimiz bazı bileşiklerin (kamferol, apigenin, kafeik asit) diğer çalışmalardaki siyah sarımsaklarda da tespit edilmediği görülmüştür. Gerek tespit edilen fenolik bileşikler gerekse miktar açısından farklılıkların bulunduğu görülmektedir. Bu farklııkların çalışmada kullanılan ticari sarımsağın çeşidi, fermantasyon koşulları (uygulanan sıcaklık, nem ve süre), morfolojik ve biyokimyasal özellikleri ile ekolojik koşullardan kaynaklandığı düşünülmektedir. Bu düşünce, araştırmacıların çalışmalarıyla da desteklenmektedir [31, 3, 33].

\section{Piyosiyanin Testi}

Piyosiyanin, $P$. aeruginosa'ya özgü mavi-yeşil renk veren bir pigment olup, önemli virülans faktörlerinden biridir. Siyah sarımsak metanol ektraktının PA01'in ürettiği piyosiyanin üzerine inhibisyon etkisine bakıldığında istatistiksel olarak anlamlı azalmanın olduğu gözlenmiştir (Şekil 3). PA01'in ürettiği piyosiyanin pigmentinin sarımsak ekstraktı ile inhibisyon oranı \%38 olarak tespit edilmiştir. Piyosiyaninin hücrede solunumu baskılayarak, siliyer fonksiyonları bozarak patogenezde rol aldığı yapılan in vitro çalışmalarla gösterilmiştir. Ayrıca kistik fibrozisli hastalarda akciğer hasarına sebep olduğu da bilinmektedir $[35,36]$. Yapılan literatür taramasında siyah sarımsak metanol ektraktının $P$. aeruginosa PA01 de piyosiyanin üretimi üzerine inhibisyon etkisini araştırıldığı bir çalışmaya rastlanmamış olup, beyaz sarımsak yağında bulunan diallil disülfit ile yapılan bir çalışmada QS sistemine ait anahtar genler olan las, rhl, pqs genlerinin regülasyonunun baskılandığı bunun neticesinde piyosiyanin biyosentezi, elastaz üretimi ve biyofilm oluşumunun engellendiği bulunmuştur [37].

Biyofilm oluşumuna siyah sarımsak metanol ekstraktının etkisine bakıldığında ise \%84 oranında güçlü inhibisyon etkisinin olduğu tespit edilmiştir. Genel değerlendirmede bitki ekstraktının kontrol PA01 ile kıyaslandığında 
biyofilm oluşumu üzerine inhibisyon etkisinin istatistiksel olarak da anlamlı olduğu $(\mathrm{P}<0.01)$ tespit edilmiştir (Şekil 3).

Biyofilm tabakası bakteriyi antimikrobiyal ajanlara ve konak bağışıklık sistemine karşı koruyarak, bakterinin konaktaki kalıcı kolonizasyonun da etkin rol oynar ve konağın iyileşme sürecini güçleştirir [38]. Yapılan birçok çalışma biyofilm oluşumunun çevreyi algılama (QS) sisteminin kontrolünde olduğunu göstermiş ve bakteriler arasında iletişimi sağlayan sinyallerin bloke edilmesi ile biyofilm oluşumunun engellenerek antibiyotiklere direncin azalacağı gösterilmiştir [39, 40]. Biyofilm oluşumunun bitkisel materyallerle baskılandığı çok fazla çalışma olup, bunu polimer oluşumunun engellenmesi, hücre yapışması ve bağlanmasının baskılanması, ekstraselüler matriksin üretiminin engellenmesi ile sağladıkları görülmüştür [41].

Literatürde biyofilm oluşumunun engellenmesi üzerine bitki kaynaklı birçok doğal ürünle çalışılmış olup siyah sarımsak ile yapılmış bir çalışmaya rastlanmamıştır.

$P$. aeruginosa'nın konakçı dokularında kolonizasyonu sağlayarak immün sistemi baskıladığı virülens faktörlerinden biri de ekstraselüler proteazlardır. Bunlar içerisinde en önemli olan iki tanesi 50-kDa alkalin proteaz AprA ve 33-kDa elastaz LasB'dir [42]. Ayrıca her iki enzim deri, akciğer ve korneada nekroza sebep olur. LasB elastaz gerek tek başına gerekse Pseudomonas tarafından üretilen diğer proteazlar ile birlikte işlev göstererek biyolojik olarak önemli birçok substratı parçalar veya inaktive eder [43]. Siyah sarımsak ile hazırlanan metanol ekstraktının elastaz üretimi üzerindeki inhibisyon etkisi elastin Kongo red (ECR) yöntemi ile araştırılmış ve sonuçta kontrol PA01 suşu ile kıyaslandığında çalışılan derişimde $(66 \mathrm{mg}) \% 28$ oranında inhibisyonun gözlenirken ve bu oranın istatistiksel olarak da anlamlı olduğu görülmüştür (Şekil 3).

Kuersetin birçok meyve, sebze ve bitki tohumunda bulunan önemli bir polifenoldür. Yapısında kuersetin içeren bitkilerle yapılan çalışmalarda elastaz üretimini baskıladığı düşünülmüştür. Ayrıca kuersetin ile yapılan bir çalışmada ise çok düşük konsantrasyonlarda (16 $\mu \mathrm{g} / \mathrm{mL}$ ) elastaz üretimi üzerine inhibisyon etki gösterdiği tespit edilmiştir [44]. $P$. aeruginosa'da elastaz üretiminin inhibisyonu üzerine siyah sarımsak metanol ekstraktı ile yapılan bir çalışmaya rastlanmamıştır.

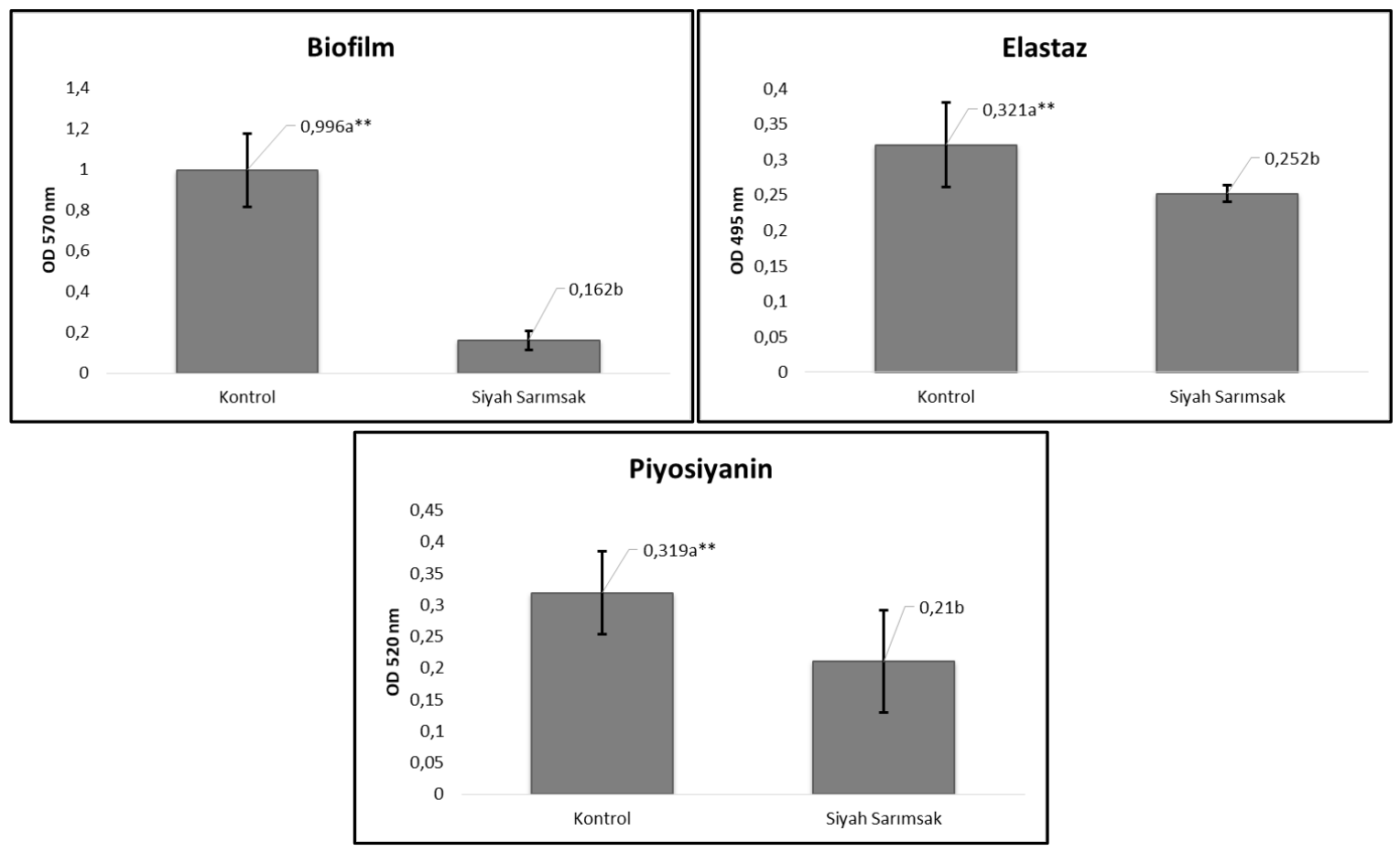

Şekil 3. Siyah sarımsak metanol ekstraktının piyosiyanin ve elastaz üretimi ile biyofilm oluşumu üzerine inhibisyon etkisi. ${ }^{* *}$ Aynı harfi taşıyan değerler arasındaki fark istatistiksel olarak önemli değildir $(P<0.01)$

\section{SONUÇ}

Sonuç olarak son yıllarda ismi sıkça duyulan siyah sarımsak, taze sarımsağın keskin kokusundan duyulan rahatsızlığa karşı iyi bir alternatif olmasının yanında, içeriğinin daha zengin olması ile de tercih sebebi olmuştur. Yapılan literatür taramasında siyah sarımsakta toplam fenolik madde tayini üzerine yapılmış bir çok 
çalışmaya rastlanmış olup, fenolik bileşik bazında yapılan çalışma sayısının az olduğu görülmüştür. Ayrıca $P$. aeruginosa'da çevreyi algılama sisteminin (QS) inhibisyonu üzerine yapılan herhangi bir çalışmaya rastlanmamıştır. Bu çalışma ile siyah sarımsakta bulunan fenolik bileşikler araştırılmış ve siyah sarımsağın Pseudomonas aeruginosa'da virülans faktörü olan elastaz ve piyosiyanin ile biyofilm oluşumu üzerine etkisi incelenmiştir. HPLC sonuçlarına göre fenolik bileşiklerden; $p$-hidroksi benzoik asit, klorojenik asit, vanillin, $p$-kumarik asit ve kuersetin saptanmıştır. Temel fenolik bileşiğin kuersetin $(7.7 \pm 1.0 \mu \mathrm{g} / \mathrm{g})$ olduğu görülmüştür.

Bakteriyel test sonuçlarına göre ise, siyah sarımsak metanol ekstraktının $P$. aeruginosa virülansında önemli rolü olan üç faktöre karşı inhibisyon etki gösterdiği bulunmuştur. En etkili inhibisyon sonucunun \%84 ile biyofilm oluşumu üzerine olduğu görülmüştür. Antibiyotik direncinin ciddi sorun olduğu son yıllarda, bakterilerle mücadelede, bitkisel droglara yönelim ve bakteriler arasındaki iletişiminin engellenerek enfeksiyon hastalıklarının oluşumunun önlenmesi umut vaat eden stratejiler arasında görülmektedir.

\section{KAYNAKLAR}

[1] Genç, S. (2017). Sarımsağın tarihçesi, türleri ve sarımsak ürünleri. TKDK, Kırsal Kalkınma Sayı 7.

[2] Rivlin, R.S. (2001). Historical perspective on the use of garlic. Journal of Nutrition, 131, 951-954.

[3] Ayaz, E., Alpsoy, H.C. (2007). Sarımsak (Allium sativum) ve geleneksel tedavide kullanımı. Türkiye Parazitoloji Dergisi, 31(2), 145-149.

[4] Kim, I., Kim, J.Y., Hwang, Y.J., Hwang, K. A., Om, A.S., Kim, J.H., Cho, K.J. (2011). The beneficial effects of aged black garlic extract on obesity and hyperlipidemia in rats fed a high-fat diet. Journal of Medicinal Plant Research, 5(14), 3159-3168.

[5] Ryu, J.H., Kang, D. (2017). Physicochemical properties, biological activity, health benefits, and general limitations of aged black garlic: A Review. Molecules, 22, 919-931.

[6] TUiK (2019). Türkiye İstatistik Kurumu, https://biruni.tuik.gov.tr/medas/?kn=104\&locale=tr.

[7] Kang, O.J. (2016). Evaluation of melanoidins formed from black garlic after different thermal processing steps. Preventive Nutrition and Food Science, 21(4), 398-405.

[8] Medina, M.A.T., Aparicio, J.P., Ortega, A.M., Rojas, R.M. (2019). Influence of variety and storage time of fresh garlic on the physicochemical and antioxidant properties of black garlic. Foods, 8, 314-324.

[9] Kimura, S., Tung, Y., Pan, M., Su, N., Lai, Y., Cheng, K. (2017). Black garlic: A critical review of its production, bioactivity, and application. Journal of Food and Drug Analysis, 25, 62-70.
[10] Zhang, Z., Lei, M., Liu, R., Gao, Y., Xu, M., Zhang, M. (2015). Evaluation of alliin, saccharide contents and antioxidant activities of black garlic during thermal processing. Journal of Food Biochemistry, 39, 39-47.

[11] Bae, S.E., Cho, S.Y., Won, Y.D., Lee, S.H., Park, H.J. (2012). A comparative study of the different analytical methods for analysis of S-allylcysteine in black garlic by HPLC. LWTFood Science and Technology, 46, 532-535.

[12] Kim, S.H., Jung, E.Y., Kang, D.H., Chang, U.J., Hong, Y.H., Suh, H.C. (2012). Physical stability, antioxidative properties, and photoprotective effects of a functionalized formulation containing black garlic extract. Journal of Photochemistry and Photobiology B: Biology, 117,104-110.

[13] Bae, S.E., Cho, S.Y., Won, Y.D., Lee, S.H., Park, H.J. (2014). Changes in S-allylcysteine contents and physicochemical properties of black garlic during heat treatment. LWT-Food Science and Technology, 55, 397-402.

[14] Angeles, T.M.M., Jesus, P.A., Rafael, M.R., Tania, M.A. (2016). Evolution of some physicochemical and antioxidant properties of black garlic whole bulbs and peeled cloves. Food Chemistry, 199, 135-139,

[15] Lu, X., Li, N., Qiao, X., Qiu, Z., Liu, P. (2017). Composition analysis and antioxidant properties of black garlic extract. Journal of Food and Drug Analysis, 25(2), 340-349.

[16] Ergin, S.Ö. (2019). The benefits of black garlic to human health. Turkish Journal of Agriculture - Food Science and Technology, 7(7), 940-945.

[17] Akan, S. (2014). Siyah sarımsak. Gıda, 39(6), 363370.

[18] Li, N., Lu, X., Pei, H., Qiao, X. (2014). Effect of freezing pretreatment on the processing time and quality of black garlic. Journal of Food Process Engineering, 38(4), 329-335.

[19] Yuan, H., Sun, L., Chen, M., Wang, J. (2018). An analysis of the changes on intermediate products during the thermal processing of black garlic. Food Chemistry, 239, 56-61.

[20] Choi, S., Cha, H.S., Lee, Y.S. (2014). Physicochemical and antioxidant properties of black garlic. Molecules, 19, 16811-16823.

[21] Medina, M.A.T., Amo, T.M., Bedmar, Z.F., Font, R., Celestino, M.R., Aparicio, J.P., Ortega, A.M., Moraga, A.A., Rojas, R.M. (2019b). Physicochemical characterization and biological activities of black and white garlic: in vivo and in vitro assays. Foods, 8, 220-239.

[22] Purev, U., Chung, M., Oh, D.H. (2012). Individual differences on immunostimulatory activity of raw and black garlic extract in human primary immune cells. Immunopharmacology and Immunotoxicology, 34(4), 651-660.

[23] Botas, J., Fernandes, A., Barros, L., Alves, M.J., Carvalho, A.M., Isabel, C.F.R. Ferreira. (2019). A 
comparative study of black and white Allium sativum L.: Nutritional composition and bioactive properties. Molecules, 24, 2194-2205.

[24] Jung, I.C., Sohn H.Y. (2014). Antioxidation, antimicrobial and antithrombosis activities of aged black garlic (Allium sativum L.). Korean Journal of Microbiology and Biotechnology, 42(3), 285-292.

[25] Lerat, E., Moran, N.A. (2004). The evolutionary history of quorum sensing systems in bacteria. Molecular Biology and Evolution, 21(5), 903-913.

[26] Henke, J.M., Bassler, B.L. (2004). Bacterial social engagements. Trends in Cell Biology, 14(11), 648656.

[27] Gomes, T., Caponio, F., Alloggio, V. (1999). Phenolic compounds of virgin olive oil: influence of paste preparation techniques. Food Chemistry, 64, 203-209.

[28] Essar, D.W., Eberly, L., Hadero, A., Crawford, I. (1990). Identification and characterization of genes for a second anthranilate synthase in $P$. aeruginosa: interchangeability of the two anthranilate synthases and evolutionary implications. Journal of Bacteriology, 172, 884-900

[29] O'Toole, G.A. (2011). Microtiter dish biofilm formation assay. Journal of Visualized Experiments, 47, 2437.

[30] Ohman, D.E., Cryz, S.J., Iglewski, B.H. (1980). Isolation and characterization of a $P$. aeruginosa PAO mutant that produces altered elastase. Journal of Bacteriology, 142, 836-842.

[31] Casas, L.M., Yusty, M.L., Hernandez, J.L. (2017). Changes in the aromatic profile, sugars, and bioactive compounds when purple garlic is transformed into black garlic. Journal of Agricultural and Food Chemistry, 65, 10804-10811.

[32] Kim, J.S., Kanga, O.J., Gweonb, O.C. (2013b). Comparison of phenolic acids and flavonoids in black garlic at different thermal processing steps. Journal of Functional Foods, 5, 80-86.

[33] Eyupoglu, O.Z. (2019). Antioxidant activities, phenolic contents and electronic nose analysis of black garlic. International Journal of Secondary Metabolite, 6(2), 154-161.

[34] Koca, I., Tekguler, B., Koca, A.F. (2016). Some physical and chemical characteristics of Taşköprü and Chinese black garlics. VII International Symposium on Edible Alliaceae, ISHS Acta Horticulturae 1143, 221-226.
[35] Karatuna, O., Yağcı, A. (2008). Pseudomonas aeruginosa'da virülans faktörleri ve quorum sensing. Türk Mikrobiyoloji Cemiyeti Dergisi, 38, 42-51.

[36] Denning, G.M., Wollenweber, L.A., Railsback, M.A., Cox, C.D., Stoll, L.L., Britigan, B.E. (1998). Pseudomonas pyocyanin increases interleukin-8 expression by human airway epithelial cells. Infection and Immunity, 66(12), 5777-5784.

[37] Li W.R., Ma Y.K., Xie, X.B., Shi, Q.S., Wen, X., Sun, T.L., Peng, H. (2019). Diallyl disulfide from garlic oil inhibits Pseudomonas aeruginosa quorum sensing systems and corresponding virulence factors. Frontier Microbiology, 9, 1-11.

[38] Maçin, S., Kıttana, F.N.A., Yılmaz, Y.A. (2017). Çeşitli klinik örneklerden izole edilen Pseudomonas aeruginosa suşlarının virulans faktörlerinin incelenmesi. Çukurova Medical Journal, 42(2), 308-313

[39] Jiang, Q., Chen, J., Yang, C., Yin, Y., Kang, Y. (2019). Quorum sensing: A prospective therapeutic target for bacterial diseases. BioMed Research International, 7, 1-15.

[40] Hong, S.H., Hegde, M., Kim, J., Wang, X., Jayaraman, A., Wood, T.K. (2012). Synthetic quorum-sensing circuit to control consortial bioflm formation and dispersal in a microfuidic device. Nature Communications, 3, 1-8.

[41] Lu, L., H.W., Tian, Z., Yuan, D., Yi, G., Zhou, Y., Cheng, Q., Zhu, J., Li, M. (2019). Developing natural products as potential anti-bioflm agents. Chinese Medicine, 14(11), 2-17.

[42] Casilag, F., Lorenz, A., Krueger, J., Klawonn, F., Weiss, S., Häussler, S. (2016). The LasB Elastase of Pseudomonas aeruginosa acts in concert with alkaline protease aprA to prevent flagellin-mediated immune recognition. Infection and Immunity, 84(1), 162-171.

[43] Nicas, T., Bradley, I., Lochner, J.E., Iglewski, B.H. (1985). The role of exoenzyme $S$ in infections with $P$. aeruginosa. Journal of Infectious Diseases, 152, 716-721.

[44] Ouyang, J., Sun, F., Feng, W., Sun, Y., Qiu, X., Xiong, L., Liu, Y., Chen, Y. (2015). Quercetin is an effective inhibitor of quorum sensing, biofilm formation and virulence factors in Pseudomonas aeruginosa. Journal of Applied Microbiology, 120, 966-974. 